\title{
Overview of The Head CT-Scan in Stroke Patients who was Treated at Muhammadiyah Hospital Palembang
}

\author{
Pratrisna Yusastra ${ }^{1}$, Indriyani ${ }^{2 *}$, Budi Utama ${ }^{3}$ \\ 1) Medical Study Program, Faculty of Medicine, Universitas Muhammadiyah Palembang, Indonesia \\ 2) Department of Anatomy, Faculty of Medicine, Universitas Muhammadiyah Palembang, Indonesia \\ 3) Department of Immunology, Faculty of Medicine, Universitas Muhammadiyah Palembang, Indonesia \\ *Corresponding author: indriyani.dr_ump@yahoo.com
}

\begin{abstract}
Background: Stroke is a collection of symptoms of neurological deficits due to sudden acute disturbance of brain function, both focal and global, caused by blockage or rupture of arteries and veins and proven by imaging and/or reflex pathology. Using CT-Scan, the description of acute phase stroke can be easier and can determine the appropriate treatment criteria for stroke. Purposes: To determine characteristic Head CT-Scan image of stroke patients hospitalized in Muhammadiyah Palembang Hospital. Methods: This study was conducted in a retrospective descriptive manner and obtained a sample of 41 stroke patients according to the inclusion and exclusion criteria using total sampling. Result: In this study, there were 28 patients $(68.2 \%)$ with ischemic stroke and 13 patients (31.7\%) with hemorrhagic stroke. Head CT-Scan image of ischemic stroke shows basal ganglia lesion $(28.5 \%)$ and the right hemisphere lesions $(57.1 \%)$ as the most predominant area. Head CT-Scan image of hemorrhagic stroke $(58.3 \%)$ had intracerebral hemorrhage with the dominant thalamic lesion area $(66.6 \%)$ and the right hemisphere $(58.3 \%)$ had the most lesions with 8 patients $(66,6 \%)$ had a midline shift. Stroke patients were treated as experienced by the elderly $(90.2 \%)$ and were dominated by the female sex $(63.4 \%)$ and are dominated by clinical symptoms of hemiparesis $(29.2 \%)$. Conclusion: Stroke patients at Muhammadiyah Palembang hospital dominated by ischemic stroke and on head CT Scan image predominantly shows lesions on the right cerebral hemisphere.
\end{abstract}

Keywords: head CT-scan image, hemorrhagic stroke, ischemic stroke

\section{INTRODUCTION}

Stroke is a collection of symptoms of a neurological deficit due to sudden acute and global impairment of brain function, caused by reduced or lost blood flow to the brain parenchyma, retina, or spinal cord, which can be caused by blockage or rupture of vessels. Arterial or venous blood, as evidenced by imaging and/or reflex pathology (1). According to WHO, 15 million people worldwide suffer a stroke every year. Indonesia has the secondhighest prevalence of stroke after Mongolia, which is 3,382.2/100,000 people based on disability-adjusted life-year (DALY) in 2018. The prevalence of stroke in Indonesia has increased by $3.9 \%$ in the last five years. Based on the health profile of Bali province, the type of stroke has a high prevalence rate in ischemic stroke (2).

According to the World Stroke Organization (WSO), approximately $60 \%$ 
of strokes occur at $<70$ years of age and $8 \%$ occur at $<44$ years of age. Stroke was more common in men (52\%) than women (48\%), be it an ischemic stroke or hemorrhagic stroke. In addition, $72.1 \%$ of strokes were caused by metabolic problems (such as increased blood pressure systole, body mass index, fasting plasma glucose (FPG), total cholesterol), while the rest was caused by atrial fibrillation and flutter (3). The incidence of stroke was also observed in other countries such as in Frederiksberg, Denmark (1989-1990) at 306/100,000 population per year and rural Porto, Portugal (1998-2000) at 305/100,000 population per year. In the Netherlands (1978-80) the incidence was quite high, reaching 289/100,000, with a relatively high population aged $\geq 65$ years. Sesto Fiorentino, Italy (2004-2005) has a relatively low incidence of stroke, namely 170/100,000 population per year. Dijon (France) also has a stroke incidence of 113/100,000 population. In Nigeria, West Africa, specifically Nigeria, the number of strokes ranges from 41/100,000 population per year (1971-74) to $316 / 100$ per year in urban Dar-es-Salaam (4).

Neuroimaging (non-surgical brain mapping images) plays an important role in stroke management and helps to make diagnoses as well as therapeutic decisions one of which is head CT scan (5). Computerized tomography (CT) is an imaging method that is most rapidly useful in identifying and differentiating brain hemorrhages or infarcts by using an ionizing $\mathrm{x}$-ray beam as a source of light which will be digitally processed by a computer to produce an internal three-dimensional image axially and coronally (6). Using CT-Scan can also help determine the appropriate treatment criteria for each form of stroke (7). In the province of South Sumatra, especially the city of Palembang, a study on identifying stroke using a head CT scan experiment was the first research study. Based on this background, researchers are interested in finding the complete description in CT scan images of stroke cases treated at Muhammadiyah Hospital Palembang in January 2018-January 2020 and see how much head CT scan is used to help diagnosing stroke at Muhammadiyah Hospital Palembang.

\section{METHODS}

This study used a retrospective descriptive method. This study was conducted from October to December 2020. The population in this study were stroke patients who performed a head CT scan and were treated at the Muhammadiyah Palembang Hospital on January 1, 2018 - December 31, 2019. The sample in this study was 41 patients who were taken by total sampling. The research variables in this study were the head CT-scan image of ischemic stroke cases, namely the lesion area and cerebral hemispheres involvement, and the head CTscan image of hemorrhagic stroke cases, namely the bleeding location, lesion area, cerebral hemispheres, and midline shift involvement, as well as the demographic description, including age, gender, and clinical symptoms. The method of collecting data in this study was secondary data, which was obtained from the subject through medical records based on the results of a validated head CT scan based on expert radiologists (radiologists) to determine the picture of lesions in stroke patients examined. This study was analyzed univariately by analyzing the frequency distribution, then the data were presented in narrative form, a distribution table of the proportion of stroke types based on age, gender, clinical symptoms, and head CT scan. This research 
has received permission from Research Ethics Committee FK Universitas Muhammadiyah Palembang No. 62/EC/KBHKI/FK-UMP/I/ 2021.

\section{RESULT}

Research has been carried out in the medical records and radiology section of the Muhammadiyah Palembang Hospital (RSMP). There were 41 data on stroke patients hospitalized in RSMP. Based on table 1, shows that most types of strokes are ischemic strokes, with age being dominated by the elderly and predominantly female.

Table 1. Distribution of Respondents Based on Type Stroke, Age and Sex Who Performed Head CT Scan

\begin{tabular}{|c|c|c|}
\hline $\begin{array}{l}\text { Type of } \\
\text { Stroke }\end{array}$ & $\begin{array}{c}\text { Frequency } \\
\text { (n) }\end{array}$ & $\begin{array}{c}\text { Percentage } \\
(\%)\end{array}$ \\
\hline Ischemic & 28 & 68.2 \\
\hline Hemorrhagi & 13 & 31.7 \\
\hline $\mathrm{c}$ & & \\
\hline Total & 41 & 100.0 \\
\hline Age & $\begin{array}{c}\text { Frequency } \\
\text { (n) }\end{array}$ & $\begin{array}{c}\text { Percentage } \\
(\%)\end{array}$ \\
\hline Adult & 4 & 9.7 \\
\hline Elderly & 37 & 90.2 \\
\hline Total & 41 & 100.0 \\
\hline Gender & $\begin{array}{c}\text { Frequency } \\
\text { (n) }\end{array}$ & $\begin{array}{c}\text { Percentage } \\
(\%)\end{array}$ \\
\hline Male & 15 & 36.5 \\
\hline Female & 26 & 63.4 \\
\hline Total & 41 & 100.0 \\
\hline
\end{tabular}

Table 2 shows the CT scan of the head in ischemic stroke patients, it is predominantly in the basal ganglia area and is dominated by lesions in the right cerebral hemisphere.

Table 2. Distribution of Respondents Based on Head CT Scan Ischemic Stroke

\begin{tabular}{lcc}
\hline \multicolumn{1}{c}{ Image } & $\begin{array}{c}\text { Frequency } \\
(\mathbf{n})\end{array}$ & $\begin{array}{c}\text { Percentage } \\
(\boldsymbol{\%})\end{array}$ \\
\hline Cortical & 6 & 21.4 \\
Basal ganglia & 8 & 28.5
\end{tabular}

\begin{tabular}{lcc} 
Thalamus & 6 & 21.4 \\
Periventricle & 5 & 17.8 \\
$\begin{array}{l}\text { Corona } \\
\text { radiata }\end{array}$ & 2 & 7.1 \\
$\begin{array}{l}\text { Internal } \\
\text { capsule }\end{array}$ & 1 & 3.5 \\
Total & 28 & 100.0 \\
\hline \multicolumn{1}{c}{ Cerebral } & Frequency & Percentage \\
hemispheres & $\mathbf{( n )}$ & $\mathbf{( \% )}$ \\
\hline Dextra & 16 & 57.1 \\
Sinistra & 12 & 42.8 \\
Total & 28 & 100.0 \\
\hline
\end{tabular}

Table 3 shows the CT scan of the head in stroke patients hemorrhagic was dominated by intracerebral hemorrhage, with an area dominated by the thalamus, $66.6 \%$ positive midline shift, and dominated by lesions in the right cerebral hemisphere.

Table 3. Distribution of Respondents Based on Head CT-Scan Hemorrhagic Stroke

\begin{tabular}{|c|c|c|}
\hline Image & $\begin{array}{l}\text { Frequency } \\
\text { (n) }\end{array}$ & $\begin{array}{c}\text { Percentage } \\
(\%)\end{array}$ \\
\hline $\begin{array}{l}\mathrm{ICH}+ \\
\text { Intraventricular }\end{array}$ & 5 & 38.4 \\
\hline Intracerebral & 7 & 53.8 \\
\hline Subarachnoid & 1 & 7.6 \\
\hline Intraventricular & 0 & 0 \\
\hline Total & 13 & 100.0 \\
\hline $\begin{array}{c}\text { Overview CT } \\
\text { scan of the } \\
\text { head }\end{array}$ & $\begin{array}{l}\text { Frequency } \\
\text { (n) }\end{array}$ & $\begin{array}{c}\text { Percentage } \\
(\%)\end{array}$ \\
\hline Cortical & 2 & 16.6 \\
\hline basal ganglia & 2 & 16.6 \\
\hline thalamus & 8 & 66.6 \\
\hline periventricular & 0 & 0 \\
\hline corona radiata & 0 & 0 \\
\hline capsule interna & 0 & 0 \\
\hline Total & 12 & 100.0 \\
\hline $\begin{array}{l}\text { Preview CT } \\
\text { scan head }\end{array}$ & $\begin{array}{l}\text { Frequency } \\
\text { (n) }\end{array}$ & $\begin{array}{c}\text { Percentage } \\
(\%)\end{array}$ \\
\hline Midline shift (+) & 8 & 66.6 \\
\hline Midline shift (-) & 4 & 33.3 \\
\hline Total & 12 & 100.0 \\
\hline
\end{tabular}




\begin{tabular}{lcc}
\hline $\begin{array}{c}\text { Cerebral } \\
\text { hemispheres }\end{array}$ & $\begin{array}{c}\text { Frequency } \\
(\mathbf{n})\end{array}$ & $\begin{array}{c}\text { Percentage } \\
(\boldsymbol{\%})\end{array}$ \\
\hline Dextra & 7 & 58.3 \\
Sinistra & 5 & 41.6 \\
Total & 12 & 100.0 \\
\hline
\end{tabular}

Table 4 shows that most stroke patients have clinical symptoms of hemiparesis.

Table 4. Distribution of Respondents Based on Clinical Symptoms in Stroke Patients

\begin{tabular}{|c|c|c|}
\hline $\begin{array}{c}\text { Clinical } \\
\text { Symptoms }\end{array}$ & $\begin{array}{l}\text { Frequency } \\
\text { (n) }\end{array}$ & $\begin{array}{c}\text { Percentage } \\
(\%)\end{array}$ \\
\hline $\begin{array}{l}\text { Hemiparesis with } \\
\text { headache, nausea } \\
\text { vomiting and } \\
\text { decreased } \\
\text { consciousness }\end{array}$ & 9 & 21.9 \\
\hline $\begin{array}{l}\text { Hemiparesis with } \\
\text { headache and } \\
\text { nausea vomiting }\end{array}$ & 7 & 17 \\
\hline $\begin{array}{l}\text { Hemiparesis with } \\
\text { headache, nausea } \\
\text { vomiting and } \\
\text { motor aphasia }\end{array}$ & 8 & 19.5 \\
\hline $\begin{array}{l}\text { Hemiparesis with } \\
\text { motor aphasia }\end{array}$ & 5 & 12.1 \\
\hline Hemiparesis & 12 & 29.2 \\
\hline Total & 41 & 100.0 \\
\hline
\end{tabular}

\section{DISCUSSION}

The study was conducted on 41 patients of data on inpatient stroke RSMP sourced in table 1 is obtained when an ischemic stroke more many of these are hemorrhagic strokes. This is consistent with some of the research conducted by Ursin where there were more ischemic strokes than hemorrhagic strokes (8). Research with the same results was carried out by Bahrudin in the Emergency Room Installation of RSU Haji Surabaya, RSU Jombang, RSU Soetomo Surabaya, it was found that the number of 171 patients was 101 ischemic stroke patients $(59.1 \%)$ and 70 hemorrhagic stroke patients (40.9\%) (9). Ischemic stroke describes a heterogeneous disease and occurs due to many underlying pathological processes. High blood pressure, carotid artery stenosis, atrial fibrillation, and certain other heart conditions, smoking, diabetes mellitus, dyslipidemia, sickle cell disease, poor diet, physical activity, and obesity are common risk factors for ischemic stroke. Intracranial atherosclerosis and carotid artery stenosis are very frequent triggers of ischemic stroke. Rupture of the plaque surface and formation of a luminal thrombus may be underlying the processes of chronic ischemic stroke. Plaque is depicted as echo-solid calcification and can be formed by the homogeneous deposition of cholesterol. Plaque can be dangerous because of the effects of stenosis, and can also damage the atherosclerotic walls and enter the bloodstream. The damaged plaque creates a thrombus which acts as an anticoagulant to the endothelial surface of the damaged local blood vessels. Intracranial atherosclerosis can cause focal or multifocal stenosis in the ICA, MCA trunks, branch points of the major MCA branches, ACA branches, A1 and A2, P1 and P2 part of the PCA, distal vertebral arteries, proximal vertebral arteries, vertebrobasilar branches, and arteries. basilar (10).

In this study, based on table 1 , it was also found that the number of stroke patients in the elderly was more than the aged patients. This case shows that stroke patients who are treated at the Muhammadiyah Palembang Hospital and carry out a CT scan of the head are predominantly over 50 years of age. Research with the same results conducted by Sofyan found 77 patients with strokes aged 40-55 years as many as 25 patients $(32.5 \%)$ and 55 years 52 patients $(67.5 \%)$ (11). Age is a very important aspect in all types of stroke. This condition can be intertwined due to several things, one of which is atherosclerosis (thickening of the 
walls of blood vessels) along with increasing age, causing all organs of the body to face a decline in function, including blood vessels located in the brain. This can cause rupture of blood vessels or narrowing of blood vessels (12). Blood vessels in the elderly tend to face degenerative changes. Changes in the structure of blood vessels become inelastic, especially the endothelial part which faces thickening of the intima, causing the lumen of the blood vessels to become small which results in obstruction of blood flow to the brain (13).

Based on table 1, it is found that the number of stroke patients with the female gender is more than the male gender. This matter proves that most stroke sufferers who are treated at the Palembang Muhammadiyah Hospital and who perform CT-Scan of the head are women. Research with similar results conducted by Dinata at the South Solok District Hospital found that there were 52 more female patients $(54.1 \%)$ of strokes, compared to 44 male patients (45.8\%) (14). Basically, men are more likely to have a stroke than women. This is possible because of the poor lifestyle such as smoking, consuming alcohol, hypercholesterolemia, and a history of heart disease, which can disturb the flexibility of blood vessels and can also cause blockages that will lead to atherosclerosis. But research conducted in the daily National Center for Health Statistics says that based on the gender of people who have an ischemic stroke at the beginning of the time, in general, the incidence of ischemic stroke is more in the female sex than in men. This matter could be related to a special situation which was said by Risk Factors Unique, namely, there are some aspects of the risk of ischemic stroke that are specifically obtained in women, a kind of pregnancy where the situation is known as gestational diabetes is a situation caused by glucose intolerance that is encountered early pregnancy and may persist even after giving birth. Estrogen plays a role as a protector in the atherosclerosis process, as a result, women who have faced menopause also have a high risk for the formation of atherosclerosis and ischemic stroke (15).

The CT scan image of the head in ischemic stroke in RSMP is obtained from Table 2, it is obtained that the position of the hypodense lesion in the cerebral hemisphere is most often in the basal ganglia region. Based on this position, the subtypes of ischemic stroke found at the Muhammadiyah Palembang Hospital are mostly lacunar types (16). However, this matter must be proven further using MRI (Magnetic Resonance Imaging) (17-19). Research conducted by Arboix (2009) states that the topography that is often seen in lacunar infarcts in the lenticular nucleus, thalamus, white matter frontal lobe, pons, basal ganglia, internal capsule, and caudate nucleus (18). The basal ganglia are found at the base of the frontal lobe and above the midbrain precisely on the substantia alba subcortical telencephalic. The nucleus of the basal ganglia exerts inhibitory and excitatory effects on the motor cortex, especially the control of muscle tone. The basal ganglia are bleeding mostly by the middle cerebral artery branches and the proximal segments of the anterior cerebral artery in the rostral basal ganglia. The basal ganglia and cerebellum affect the output through the thalamus down the corticobulbar as well as the corticospinal routes originating from the motor and premotor cerebral cortex. Therefore, lesions in the basal ganglia will affect normal motor output (20). Lacunar infarction is a deep subcortical infarction that usually involves the perforation of an 
artery in the deep gray matter and brainstem. Lacunar infarcts are usually less than $1 \mathrm{~cm}$ in dimensions and not more than $1.5 \mathrm{~cm}$ in diameter (21). The majority of lacunar infarcts are located in the area of the lenticular branches as well as the deep perforator medullary branches of the anterior, the branches thalamoperforating, thalamogeniculate, and middle cerebral arteries of the cerebral arteries, and the paramedian branches of the basilar arteries (18). The trigger for the apparent lacunar infarction caused by the artery is a deep arteriole between 100 and $400 \mu \mathrm{m}$ in diameter, originates directly from the large cerebral artery, does not have collateral branches and terminal anastomoses, and supplies blood to the deepest and closest areas to the midbrain and trunk. the brain for example in the middle cerebral artery. Most of the patients with lacunar infarction face high blood pressure and many of them are in elderly patients (18).

In this study, based on Table 2, it was also found that the number of ischemic stroke patients with lesions in the right hemisphere was higher than that of the left hemisphere. These results were similar to the research conducted by Pribadhi at the Neurobehavior and Neurosurgery Polyclinic of Sanglah Hospital, Denpasar, which was obtained from 47 ischemic stroke patients, 22 patients $(46.8 \%)$ left hemisphere lesions, and 25 patients $(53.2 \%)$ right hemisphere lesions (22). Another research conducted by Elim regarding the results of CT scan images in patients with non-hemorrhagic stroke reported that non-hemorrhagic stroke cases were very common in men aged 65 years, with the most frequent position of the lesion being in the right hemisphere (23). Research shows that the anatomy and histology between the left and right hemispheres are different. This comparison makes the specificity of the function of each hemisphere exist and if there is a disturbance to damage it will show different dominance of defects as well (24).

Based on table 3, it is obtained that the type of bleeding of hemorrhagic stroke patients who were treated at the Palembang Muhammadiyah Hospital and performed head CT scan was predominantly intracerebral hemorrhage. Research with a similar result was conducted by Mullins from 691 patients with stroke obtained that 25 patients $(3.6 \%)$ had bleeding. 23/25 (92\%) of patients included intraparenchymal hemorrhage, 1/25 (4\%) of patients were included in a mixture of intraparenchymal and subarachnoid hemorrhages and $1 / 25$ (4\%) were subdural hemorrhages (25). Intracerebral hemorrhage accounts for $10-15 \%$ of cases of initial stroke and is dominant in hemorrhagic strokes. Rupture of cerebral blood vessels causes the discharge of blood to the brain parenchyma tissue, cerebrospinal fluid space around the brain, or a mixture of both. The hemorrhage disrupts the brain nerve fibers through compression of the brain and also by the hematoma which causes ischemia in the surrounding tissue. The increase in intracranial pressure in turn will cause herniation of brain tissue and pressure on the brain stem. Triggers of intracerebral hemorrhage include high blood pressure, aneurysms, arterial malformations, neoplasms, coagulation disorders, anticoagulants, vasculitis, trauma, and idiopathic (26).

Based on Table 3, it is also found that the position of the hyperdense lesion of the cerebral hemispheres in hemorrhagic stroke is the most commonly found in the Thalamus. The thalamus is one of the most common positions for bleeding and includes deep $\mathrm{ICH}$ (deep ICH) (27). In the research conducted by Chhetri and Raut, there were 36 patients with intracerebral hemorrhage. Thirty-three patients $(91.66 \%)$ faced 
primary intracranial hemorrhage. The most frequently affected areas were the basal ganglia and the internal capsule (66.66\%), followed by the thalamus $(21.21 \%)$, the temporoparietal lobe (9.09\%), and the posterior fossa $(3.03 \%)$ (21). Supratentorial ICH is divided into lobar ICH (the center of the bleeding zone is in the white-gray matter junction) and deep ICH (the center of the bleeding zone in the basal ganglia and thalamus). If the zone participating in a large ICH includes lobar as well as deep it is likely to be deep in origin (28). The thalamus flanks the III ventricle and is divided into 3 important regions by the internal medullary lamina which is shaped like a Y letter. The end of the Y shape is the anterior nuclei, the ventrolateral nuclei (lateral and medial nuclei) in the lateral part, and the medial nuclei in the medial part. The thalamus has a basic role as a station for relay all cutaneous and visceral sensory receptor stimuli, auditory and visual stimuli, stimuli from the hypothalamus, cerebellum, and brainstem reticular formation. All of these stimuli are processed in the thalamus before they are sent to other structures, a small part to the striatum and mostly to the cerebral cortex. The thalamus also has another task, which is to modulate motor function through the feedback loop with the motor cortex, basal ganglia, and cerebellum. It also shows that the thalamus affects normal motor output when there is a lesion in the thalamus. Some natural nuclei are part of ARAS which means managing normal consciousness (29).

Based on table 3, it is shown that the majority of hemorrhagic stroke patients who are treated at the Muhammadiyah Hospital Palembang on the CT-Scan of the Head are found in the midline shift. This is caused by the mass increase in the intracranial, which in this case is blood which will automatically increase the Intracranial Pressure (ICP) (30). Massive increase in ICP will push the brain mass to the contralateral direction, which is a form of compensation. This will cause the effect of injury to the contralateral cerebral hemisphere (31). Midline shift, also known as midline shift, is the shift of the brain across its midline. There are 3 important structures, that are generally observed when measuring midline shift. A very important form is the septum pellucidum, which is a flat, linear arrangement of tissue that lies between the right and left ventricles. Two other important forms of the midline are the third ventricle and the pineal gland (32). Another effect of midline shift is the formation of brain stem distortion which can cause serious dysfunction as evidenced by abnormal posture and pupillary failure to myosis when responding to light (33). One of the important challenges in ICH is the formation of perihematomal edema that is created immediately after ICH which contributes to an increase in perihematomal volume by approximately $75 \%$ which contributes to the midline shift. Edema formation is initiated when red blood cells in the hematoma begin to lysis and hemoglobin degradation products are deposited into the brain parenchyma, thereby initiating a strong inflammatory response (31).

Table 3 also shows intracerebral hemorrhage in hemorrhagic stroke patients who were treated at RSMP and performed CT-Scan of the dominant head occurring in the right hemisphere. Research with similar results conducted by Foerch (2005) on hemorrhagic stroke with intracerebral hemorrhage of 1757 patients, found 912 patients $(51.9 \%)$ were in the right hemisphere and 845 patients $(48.1 \%)$ were in the left hemisphere (34). ICH is often the result of high blood pressure. Chronic ICH 
will appear as hyperdense, round, or round lesions on a CT scan of the head without contrast. ICH often extends to the intraventricular, particularly if it originates from the basal ganglia and brainstem (28). Primary ICH is generally a manifestation of underlying small vessel disease. First, prolonged high blood pressure causes high blood vasculopathy which results in microscopic degenerative changes in the walls of small to medium vessels, known as lipohyalinosis. This will cause degenerative changes in the walls of blood vessels characterized by the disappearance of smooth muscle cells, thickening of the walls, narrowing of luminal, formation of microaneurysms, and micro-bleeding. Following an early rupture of the blood vessels, the hematoma causes direct mechanical injury to the brain parenchyma (35).

In this study, based on Table 4, most of the stroke patients had clinical symptoms of hemiparesis. Hemiparesis occurs due to partial lesions in either the corticobulbar or corticospinal tracts due to low blood supply or rupture of vessels in the brain tissue (36). Damage to all sides of the pyramidal cortex gives rise to Upper Motor Neuron (UMN) paralysis of the contralateral body. This is because $85 \%$ of the corticobulbar tracts will cross at the decussation pyramid before they are connected to the corticospinal tract (26). If the lesion only affects one hemisphere, it is called a hemiparesis (only one part of the limbs is limp). When it affects both parts, it is called duplex hemiparesis (36). Clinical manifestations such as decreased consciousness, headaches and nausea, and vomiting are the impact of increased intracranial pressure in stroke patients where an increase in intracranial pressure that exceeds the limit will interfere with the function of ARAS
(Ascending Reticular Activating System) as a center of consciousness and Chemoreceptor Trigger Zone as a center for nausea and vomiting (31).

\section{CONCLUSION}

Stroke patients in hospitalized Muhammadiyah Hospital Palembang period 1 January 2018-31 December 2019 most occurring in old age and dominated by women. Ischemic stroke is the most common type of stroke and a head CT scan image dominantly shows lesions on the right cerebral hemisphere in ischemic stroke.

\section{ACKNOWLEDGMENT}

We would like to thank the directors of the Palembang Muhammadiyah Hospital and the Faculty of Medicine, Universitas Muhammadiyah Palembang for providing us with support in this study.

\section{CONFLICT OF INTEREST}

Authors state they have no conflict of interest, and no affiliation or connection to or with any entity or organization, which may raise a question of bias in discussion and conclusion of the manuscript.

\section{REFERENCES}

1. Perhimpunan Dokter Spesialis Saraf Indonesia. Panduan Praktik Klinis Neurologi. 2016.

2. Made N, Sultradewi T, Dharmawan DK, Fatmawati H. Gambaran faktor risiko dan tingkat risiko stroke iskemik berdasarkan stroke risk scorecard di RSUD Klungkung. 2019;10(3):720-9.

3. Lindsay MP, Norrving B, Sacco RL, Brainin M, Hacke W, Martins S, et al. World Stroke Organization (WSO): Global Stroke Fact Sheet 
2019. Int J Stroke [Internet]. 2019

Oct 1 [cited 2021 Mar 11];14(8):806-17. Available from: https://pubmed.ncbi.nlm.nih.gov/31 658892/

4. Thrift AG, Cadilhac DA, Thayabaranathan T, Howard G, Howard VJ, Rothwell PM, et al. Global stroke statistics. Int J Stroke [Internet]. 2014 Jan 19 [cited 2021 Mar 11];9(1):6-18. Available from: http://journals.sagepub.com/doi/10. 1111/ijs. 12245

5. Nowinski WL. Human Brain Atlases in Stroke Management. Neuroinformatics [Internet]. 2020 Oct 1 [cited 2021 Mar 11];18(4):549-67. Available from: /pmc/articles/PMC7498446/

6. A. E Noor J, Normahayu I. Dosis Radiasi dari Tindakan CT-Scan Kepala. J Environmental Eng Sustain Technol. 2014 Nov 1;1(2):84-91.

7. Wittenauer R, Smith L. Background Paper 6.6 Ischaemic and Haemorrhagic Stroke. 2012.

8. Usrin I, Mutiara E, Yusad Y, Biostatistika AP, Informasi D, FkmUsu K. Pengaruh hipertensi terhadap kejadian stroke iskemik dan stroke hemoragik di ruang neurologi di Rumah Sakit Stroke Nasional (RSSN) Bukit Tinggi. J Kebijakan, Promosi Kesehat dan Biostat. 2011;2(2):2-8.

9. Bahrudin M. Model Diagnostik Stroke Berdasarkan Gejala Klinis. Saintika Med [Internet]. 2012 Sep 10 [cited 2021 Mar 11];6(2). Available from: https://ejournal.umm.ac.id/ index.php/sainmed/article/view/106 3

10. González RG, Hirsch JA, Lev MH,
Schaefer PW, Schwamm LH. Acute ischemic stroke: Imaging and intervention. Acute Ischemic Stroke: Imaging and Intervention. Springer Berlin Heidelberg; 2006. 1-297 p.

11. Muhrini Sofyan A, Yulieta Sihombing I, Hamra Y, Pendidikan Dokter UHO PF, Neurologi UHO BF, Ilmu Penyakit Dalam UHO BF. Hubungan Umur, Jenis Kelamin, dan Hipertensi dengan Kejadian Stroke. J Medula [Internet]. 2015 Mar 27 [cited 2021 Mar 11];1(1). Available from:

http://ojs.uho.ac.id/index.php/medul a/article/view/182

12. Ramadhini AZ, Angliadi LS, Angliadi E. Gambaran Angka Kejadian Stroke Akibat Hipertensi di Instalasi Rehabilitasi Medik BLU RSUP Prof. DR. R. D. Kandou Manado Periode Januari - Desember 2011. e-CliniC [Internet]. 2013 Nov 12 [cited 2021 Mar 11];1(2). Available from: https://ejournal.unsrat.ac.id/index.p hp/eclinic/article/view/3281

13. Characteristic RB, Laily SR, Timur J. Relationship Between Characteristic and Hypertension With Incidence of Ischemic Stroke. J Berk Epidemiol. 2017;5(1):48-59.

14. Dinata CA, Safrita YS, Sastri S. Gambaran Faktor Risiko dan Tipe Stroke pada Pasien Rawat Inap di Bagian Penyakit Dalam RSUD Kabupaten Solok Selatan Periode 1 Januari 2010 - 31 Juni 2012. J Kesehat Andalas [Internet]. 2013 May 1 [cited 2021 Mar 11];2(2):57. Available from: http://jurnal.fk. unand.ac.id

15. Letelay ANA, Huwae LBS, Kailola NE. Hubungan Diabetes Melitus 
Tipe II dengan Kejadian Stroke pada Pasien Stroke di Poliklinik Saraf RSUD Dr. M. Haulussy Ambon Tahun 2016. Molucca Medica [Internet]. 2019 Jun 19 [cited 2021 Mar 11];1-10. Available from: http://ojs3.unpatti.ac.id/index.php/m oluccamed

16. Amarenco P, Bogousslavsky J, Caplan LR, Donnan GA, Hennerici MG. Classification of stroke subtypes [Internet]. Vol. 27, Cerebrovascular Diseases. Cerebrovasc Dis; 2009 [cited 2021 Mar 11]. p. 493-501. Available from:

https://pubmed.ncbi.nlm.nih.gov/19 342825/

17. Phillips SJ, Dai D, Mitnitski A, Gubitz GJ, Johnston KC, Koroshetz WJ, et al. Clinical diagnosis of lacunar stroke in the first 6 hours after symptom onset: Analysis of data from the Glycine Antagonist in Neuroprotection (GAIN) Americas trial. Stroke [Internet]. 2007 Oct [cited 2021 Mar 11];38(10):270611. Available from: /pmc/articles/PMC2747476/

18. Arboix A, Martí-Vilaita JL. Lacunar stroke [Internet]. Vol. 9, Expert Review of Neurotherapeutics. Taylor \& Francis; 2009 [cited 2021 Mar 11]. p. 179-96. Available from: https://www.tandfonline.com/doi/ab s/10.1586/14737175.9.2.179

19. Arba F, Mair G, Phillips S, Sandercock P, Wardlaw JM. Improving Clinical Detection of Acute Lacunar Stroke: Analysis from the IST-3. Stroke [Internet]. 2020 [cited 2021 Mar 11];51(5):1411-8. Available from: https://pubmed.ncbi.nlm.nih.gov/32
268853/

20. Putra K, Putri SS, Sundari A. Referat Neuro-Anatomi. 2017.

21. Chhetri P, Raut S. Computed tomography scan in the evaluation of patients with stroke. J Coll Med Sci [Internet]. 2012 Sep 12 [cited 2021 Mar 11];8(2):24-31. Available from: https://www.nepjol.info/index.php/J CMSN/article/view/6834

22. Pribadhi H, Putra IBK, Adnyana IMO. Perbedaan Kejadian Depresi Pasca-Stroke pada Pasien Stroke Iskemik Lesi Hemisfer Kiri dan Kanan di RSUP Sanglah Tahun 2017. E-Jurnal Med Udayana [Internet]. 2019 [cited 2021 Mar 11];8(3). Available from: https://ojs.unud.ac.id/index.php/eum /article/view/50001

23. Elim C, Tubagus V, Ali RH. Hasil pemeriksaan CT scan pada penderita stroke non hemoragik di Bagian Radiologi FK Unsrat/SMF Radiologi RSUP Prof. Dr. R. D. Kandou Manado periode Agustus 2015 - Agustus 2016. e-CliniC [Internet]. 2016 Jul 12 [cited 2021 Mar 11];4(2). Available from: https://ejournal.unsrat.ac.id/index.p hp/eclinic/article/view/14398

24. Prayoga M, Fibriani AR, Lestari N. Perbedaan Tingkat Defisit Neurologis Pada Stroke Iskemik Lesi Hemisfer Kiri dan Kanan. Biomedika. 2017 Jan 9;8(2).

25. Mullins ME, Lev MH, Schellingerhout D, Gilberto Gonzalez R, Schaefer PW. Intracranial Hemorrhage Complicating Acute Stroke: How Common Is Hemorrhagic Stroke on Initial Head CT Scan and How Often Is Initial Clinical Diagnosis of Acute 
Stroke Eventually Confirmed? Am J Neuroradiol. 2005;26::2207-2212.

26. Mahmudah R. Left Hemiparesis e.c Hemorrhagic Stroke [Internet]. Vol. 2, Fakultas Kedokteran Universitas Lampung Medula. 2014 Jun [cited 2021 Mar 11]. Available from: https://juke.kedokteran.unila.ac.id/i ndex.php/medula/article/view/412

27. Smith EE, Rosand J, Greenberg SM. Imaging of Hemorrhagic Stroke [Internet]. Vol. 14, Magnetic Resonance Imaging Clinics of North America. Magn Reson Imaging Clin N Am; 2006 [cited 2021 Mar 11]. p. 127-40. Available from: https://pubmed.ncbi.nlm.nih.gov/16 873007/

28. Yuyun Y. Yuyun Yueniwati. Malang: UB Press; 2016. 388 p.

29. Sihanto RD. Neuroanatomi Sistem ARAS (Ascending Reticular Activating System). 2017.

30. Affandi IG, Panggabean R. Pengelolaan Tekanan Tinggi Intrakranial pada Stroke [Internet]. Vol. 43, Cermin Dunia Kedokteran. 2016 Mar [cited 2021 Mar 11]. Available from: http://www.cdkjournal.com/index.p hp/CDK/article/view/30

31. Ully H, Mochamad D. Patofisiologi Dan Penatalaksanaan Edema Serebri. Mnj. 2017;03(02):94-107.

32. Xiao F, Chiang I-J, Wong J-M, Tsai $\mathrm{Y}-\mathrm{H}$, Huang K-C, Liao C-C. Automatic measurement of midline shift on deformed brains using multiresolution binary level set method and Hough transform. Comput Biol Med [Internet]. 2011 Sep 30 [cited 2021 Mar 11];41(9):756-62. Available from: https://linkinghub.elsevier.com/retri
eve/pii/S0010482511001314

33. Gruen P. Surgical management of head trauma [Internet]. Vol. 12, Neuroimaging Clinics of North America. Neuroimaging Clin N Am; 2002 [cited 2021 Mar 11]. p. 339-43. Available from: https://pubmed.ncbi.nlm.nih.gov/12 391640/

34. Foerch C, Misselwitz B, Sitzer M, Berger K, Steinmetz H, NeumannHaefelin T. Difference in recognition of right and left hemispheric stroke. Lancet [Internet]. $2005 \mathrm{Jul} 30$ [cited 2021 Mar 11];366(9483):392-3. Available from: https://pubmed. ncbi.nlm.nih.gov/16054939/

35. Caceres JA, Goldstein JN. Intracranial Hemorrhage [Internet]. Vol. 30, Emergency Medicine Clinics of North America. W.B. Saunders; 2012 [cited 2021 Mar 11]. p. 771-94. Available from: https://pubmed.ncbi.nlm.nih.gov/22 974648/

36. Aulina S, Bintang K, Jumraini. Modul Lemah separuh badan. Makassar; 2016. 